\title{
Formation of Female Blends in Russian Folktales
}

\author{
Lidia Kovalchuk \\ Candidate of Philological Sciences, Chelyabinsk State University Russia, 454021 \\ Chelyabinsk, Brat'ev Kashirinyh st., 129; kovalchuklidia@yandex.ru
}

\section{Doi:10.5901/mjss.2015.v6n6s5p11}

\begin{abstract}
This article is devoted to the study of blend formation in Russian folktales. It aims at the study of heroines' origin and the revelation of Slavic traditions that gave rise to folktale plots. The research is built on the conceptual integration theory by $G$. Fauconnier and M. Turner. Images of folktale heroines are analyzed as blends yielded by separate input spaces; these input spaces in their turn are united by the generic space that is presented by cultural peculiarities and customs. Depending on types of input spaces all folktale blends were divided into three groups: anthropomorphic, zoomorphic and artefactual. The result of the research shows that Russian folktales appeared due to interaction of imagination and everyday experience by means of exaggeration and rethinking. The decodation of the tale context with the help of the blending theory reveals the origin of heroines' images and helps to understand the mindset of Russian people.
\end{abstract}

Keywords: blend; input space; conceptual integration; generic space; folktales.

\section{Introduction}

Folktales go back to the archaic epoch and reflect figurative comprehension of reality that surrounded our ancestors. It is traditionally believed that myths, in a close connection with rituals, ceremonies and rites of initiation, served as the origin of folktales.

Folktales as well as myths, in this or that way, illustrate a primitive way of thinking. There are three main aspects that reflect the peculiarities of how ancient people interpreted the world. They are animism (animation of nature), anthropomorphism (imposition of human features onto nature, animals, and things), and totemism (belief in the idea that people originated from animals). Their features have been preserved in tales and now serve as evidences of a highly metaphorical content of this genre.

Metaphorization due to its ability to explain one thing via another was an important tool of getting knowledge or comprehending the external world by means of something known. The metaphoric way our ancestors used to interpret the world is reflected in myths and folktales. Although many centuries later the real essence of this metaphoric context was forgotten and got to be perceived as something fantastic or unreal, it is still possible to reveal what's been hidden for centuries. The theory of blending by G. Fauconnier and M. Turner (2006) enables to decipher metaphoric context by addressing input spaces that serve as a basis for projecting one thing onto another.

\section{Research Materials and Methods}

The theory of blending is based on input mental spaces that, with the help of the cross-space mapping, yield another mental space, the blend. The blend partially inherits features of the input spaces and possesses an emergent structure of its own. One more essential component of this process is the so-called generic space. It reflects some common structure projected from the inputs (Turner, 2014).

Blending works in the same way as metaphor does. G. Fauconnier points out various kinds of 'mappings between cognitive domains that are set up when we think and when we talk': pragmatic function mappings are based on metonymy and synecdoche, schema mappings refer to grammatical constructions, and projection mappings deals with metaphors (Fauconnier, 1999). In order to understand how folktale metaphors, or blends, were formed, it is important to analyze their input spaces and the peculiarity of mappings between them.

This research is based on studying Russian female folktale images through the theory of blending. Female images are very metaphoric in their core because they carry traces of ancient rituals and beliefs. The collection of tales by A.N. Afanasjev served as a material for analysis. We have chosen tales with women as main heroines and divided the received images into groups. Groups are determined by the types of input spaces used to form the blend. They are 
anthropomorphic (referring to a man), zoomorphic (referring to animals) and artefactual (referring to an artifact). Input spaces were analyzed from the point of their meaning in Slavic culture.

\section{Research Results and Discussion}

Russian folktale heroines are often associated with animals, things or other images. If to look back to the Slavic culture, it comes as no surprise how these images appeared.

Folktales as well as myths are the most ancient types of getting knowledge and sharing it with other generations. These genres appeared at the time when the man didn't separate themselves from the natural, animal world, or the world of things, but conceptualized the existing reality via their own perception. This is the reason why anthropomorphism in folktales is mostly expressed by carrying human traits over nature, animals and things.

\subsection{Anthropomorphic blends}

Projection mappings create female folktale blends with the help of the so called 'mirror reflection'. On the one hand, nature is assigned with female anthropomorphic features, such as character traits, the manner of behaviour, and lifestyle. On the other hand, natural images are projected on the woman, enduing her with features of natural phenomena, animals and plants.

Female folktale images appeared from Slavic traditions and beliefs but were subjected to metaphorical transformations which can be revealed through blending. The most popular and recognizable blend that refers to the group of anthropomorphic blends is Baba-Yaga.

Baba-Yaga, living far in the deep forest, in Russian folktales is associated with the motif of conducting the hero into another world, where she herself plays the role of the conductor. This tradition goes back to the clan system, where sacrificers were in charge of the rituals of initiations. This ritual took place when a boy got matured and became a rightful member of the community, only then he could take somebody to wife. The ritual held different forms, but it always meant the end of the old life and resurrection to a new one. Vladimir Propp describes the rituals of initiation and the way they are presented in tales in a very detailed way (Propp, 2000), but we are interested not in the ritual but in the image of sacrificers who conducted them. Sacrificers were always women and it was them who gave birth to the image of BabaYaga.

These women lived in forest and prepared boys of 10-12 years old for the maturity by means of subjecting them to different trials. Compare it with the plot of the tale Animal milk, where Baba-Yaga helps the hero to overcome difficulties on his way to the Faraway Kingdom:

She gave him food and drink and put to bed. Next morning she gave Prince Ivan a dog and a towel, "When you see a big river on your way impossible to pass, wave one end of the towel - the bridge will appear; when you pass the river, wave another end - the bridge will disappear." 1 (Afanasjev, 1985: 83)

In many tales Baba-Yaga plays the role of the fairy helper, she gives heroes some advice and gifts. But in most tales she tries to kill them. Such ambiguity of her perception is connected with the change of the clan system and subsequent antagonism against women-sacrificers. After this, they were allotted with evil, demonic traits. In the tale The magic swan-geese she does not seem to be a nice old woman, she snatches children to eat them:

"Baba-Yaga has gone to the bath house to stoke the fire. She is going to stew you, put in the oven, roast, eat you up and ride on your bones" (Afanasjev, 1985, 334).

As sacrificers, Baba-Yaga always lives in the forest which is always described with epithets dark and mysterious. Firstly, it can be explained by the tradition to conduct rituals of initiation in the woods. Secondly, in many nations, including the Slavs, forest was considered to be the entry to the spirit world. Baba-Yaga can rule over animals and birds, which is also symbolic as the death was thought to be the change of one form of life into another, mostly that of animals or birds. That's why they are always present in tales. For example, they help to kidnap children (The magic swan-geese) or they are given to main heroes as helpers (The tale about gold, silver and copper kingdoms). Anyway the participation of animals and birds in the plot opens the road to the Faraway Kingdom, or another world.

The izbushka, where Baba-Yaga lives, stands on the border of these worlds and reminds domovina, or coffin.

${ }^{1}$ Here and further the translation is made by the author of the article. 
Domovina was a hut where dead people were buried. It stood above the earth on high stubs with protruding roots, which looked like chicken legs. That is how the fairytale expression hut on chicken legs appeared. What is also interesting is the fact that it was forbidden to make an entry to the domovina from the side of the settlement, only from the side of the forest. So, when heroes in tale encounter Baba-Yaga's hut, they always say: 'Izbushka, Izbushka! Stand with back to the forest and front towards us'.

Baba-Yaga herself looks half alive, half dead. She is presented as an old humped woman with the hooknose and bony leg ('Baba-Yaga, bony leg'). This bony leg and her skeleton look is one of the evidences of her belonging to another world. One more evidence is the famous fabulous phrase 'Foo!Foo! I smell a smell that is Russian'. Russian smell means the smell of a living person as the dead and alive smell differently.

The English equivalent for Baba-Yaga is hag or wicca, but in English fairytales they are portrayed in other ways and have nothing in common with the Russian image. Baba-Yaga is a complex blend that has been formed for centuries and, as a result, has absorbed features of different epochs. Although many scholars, for example V. Propp (1997), devoted their attention to this image, there are still many mysteries connected with it, especially those referring to the etymology of the word.

\title{
3.2 Zoomorphic blends
}

Zoomorphic blends are closely related to anthropomorphic blends and, in comparison with other types, occur in tales most frequently. Thus, the image of the snake princess exists in many Russian folktales: The hunter and his wife, The snake princess, Katigoroshek and so on. This blend combines two input spaces: woman and snake, the latter of which played an important role in many cultures. Snakes accompanied various female goddesses all over the world: The snake goddess in Minoan culture, Nüwa in China, Brighid in Celtic mythology, etc.

The Slavic cult of the snake goes back to ancient totemism. There was a belief that departed souls settled in snakes, so snakes were held in reverence (Dmitriev, 1998). In the encyclopedia Slavic mythology it is stated that in legends and spells girls were often turned into snakes as a sign of their wisdom (2002: 187). Similar ideas are traced in Russian folktales. Young beautiful women turn into snakes for the sake of salvation and get out of the burning flame which symbolizes the spirit world:

\begin{abstract}
"Kazak, be so kind! Save me from death" - "How can I save you? There is flame everywhere. I can't even approach to you." - "Put your pike into the flame and l'll get out." Kazak put the pike into the flame, and turned his back on terrible heat. Straight away a beautiful girl turned into a snake, crept on the pike, climbed on him, coiled tree times round his neck and took its tail into its mouth. (Afanasjev, 1985: 268).
\end{abstract}

As a result, we get two input spaces which are united by ancient cultural beliefs that in the process of conceptual integration form a generic space. In folktales snake-princesses are usually clever and beautiful women who change their appearances in the same way as snakes shed their skin.

The motif of human transformation is also reflected in bird images, for example swan princess. The importance of this image has got its occurrence in Russian metaphoric expressions: swanneck, floating like a swan, white swan. The blend swan princess is often associated with beauty and purity, but why?

In Slavic mythology swans were treated as sacred birds. It was forbidden to kill them and eat their meat. The beauty and graciousness of these birds gave rise to legends about swan maidens. Swan maidens were supposed to be elegant, mystical creatures that rule the roost of nature. In Slavic culture there was even a tradition among girls to put on white dresses with long sleeves and dance altogether to music (Gura, 1997). They imitated swan dance thus highlighting their chasteness. In the Russian language the word swan itself is of feminine gender and is usually used with the epithet white.

The reverence of these birds is reflected in folktales. The blending of the female and the bird images is brightly portrayed in the appearance of the main heroine. In the tale Danilo the Luckless the servant of Knyaz Vladimir sets out to the Water King to fulfill his duty and meets the swan princess:

"I want the lovely Swan Maiden to stand before me! Let her body be seen through her feathers, let her bones be seen through her body, let it be seen through her bones how from bone to bone the marrow flows, words like pearls intersperse."(Afanasjev, 1985, p. 364)

For the modern reader the woman who has feathers and looks like a bird seems to be more than strange, but according to fairytale canons it is an ideal of perfection. Such an effect is achieved with standard folktale metaphors, lik 
swan-bird, beautiful maiden, from bone to bone the marrow flows, words like pearls intersperse, and frequent repetition of clipped forms of adjectives young girl, coloured dress. In this description the ritual of unmarried girls to get dressed as swans is discernible. Once again the generic space of two inputs is stipulated by cultural background.

Therefore, the belief of the people in the power of animals and birds as well as the ritual to disguise themselves for different purposes gave rise to folktale images. Of course male and female images are different because of different roles they played at those times, but these images are not spontaneous either. It is necessary to point out that not only animals were used as totems and symbols, man-made things were also conferred with powers.

\title{
3.3 Artefactual blends
}

Historically, people believed that any thing made by hands carried part of its creator's soul. Due to this, some things, they were called fetishes, were considered to be dowered with supernatural powers. In Russian folktales such fetishes present the incarnation of the deceased person's soul.

If to look back to the Slavic culture, it comes as no surprise why dolls are often used in the folktale narration as fetishes. The source of their origin is ancient rituals of life and calendar cycles. Dolls served as talismans for protection. They were sacrificed instead of a living person, but later when rituals of sacrifice were turned into holidays they were burned for the symbolic meaning. Russian people still have this tradition in the form of Maslenitsa.

Dolls were made for different occasions like weddings or child birth, but they were always passed through female lineage. The traditional Slavic doll was faceless as it was believed that spirits can penetrate into it via its mouth and eyes. The genetical connection of dolls with the under world was marked by V. Propp. He wrote that dolls represent the deceased person, that's why they should be fed. If you feed the doll, then the incarnated soul of the dead person will give you help (Propp, 2000).

In Russian folktales dolls are main heroines' deceased mothers who help them to overcome difficulties. On the deathbed the woman blesses her daughter and gives her a doll, which later helps to surmount obstacles. The plot and the obstacles can differ, but the general idea is repeated from tale to tale: Vasilisa the Fair, Annushka, Knyaz Danilo Govorilo:

\begin{abstract}
On her deathbed the merchant's wife called her little daughter to her, took out from under the bed-clothes a doll, gave it to her, and said, "Listen, Vasilissa, dear; remember and obey these last words of mine. I am going to die. And now, together with my parental blessing, I bequeath to you this doll. Keep it always by you, and never show it to anybody; and whenever any misfortune comes upon you, give the doll food, and ask its advice. When it has fed, it will tell you a cure for your troubles." Then the mother kissed her child and died. (Afanasjev, 1984, p. 127). ${ }^{2}$
\end{abstract}

This extract describes the process of the incarnation of the woman's soul into the doll. After her death the doll becomes alive and starts helping the girl in everything she needs: form doing her housework to giving advice. Thus, we see that the metaphoric projection from the input woman onto the input doll in folktales happened because of the Slavic belief in the totemic meaning of the toy. Although many years have passed since old traditions were alive, we still believe in the power of things.

\section{Conclusion}

As any other folklore genre, folktales have passed from generation to generation in an oral form. This led to changes in plots and interpretations. Only several centuries ago folktales acquired a written form and started to be used only for esthetic function, thus having lost ritual and sacral meanings. Nowadays folktales are being studied in linguistics, philology, historical sciences, folkloristics and ethnology, but they still preserve many mysteries.

The history of any nation has always been connected with its tale heritage. Folktales were initially created as an attempt to explain reality by means of imposing peculiarities of the natural world on the life of the society. The blending of ideas in tales carries a deep pragmatic sense. Folktales present a mixture of different ideas that at the first gaze seem to be quite ridiculous and fantastic, though these ideas were not blended spontaneously but are the result of long lasting traditions. As a lot of rituals were carried out by women, the later play an important part in folklore heritage. The notion of woman is the basic concept that is characterized by strongly marked national and cultural characteristics. Its interpretation is based upon stereotypes which have appeared due to biological and social functions carried by women. It is an input space that serves for yielding various blends both in everyday speech and in tales.

2 Translation is taken from the book Russian Fairy Tales. A Choice Collection of Muscovite Folk-lore by W. R. S. Ralston, p. 158. 


\section{Acknowledgements}

The publication of the article is supported by the Russian Science Foundation for Humanities (RGNF), grant N 15-0400455 "Analogue and cognitive processes in linguocreative activity of the personality".

\section{References}

Afanasjev, A. N. (1984). Narodnuye Russkie Skazki [Russian folktales] (V.1). Moscow: Nauka.

Afanasjev, A. N. (1985). Narodnuye Russkie Skazki [Russian folktales] (V.2). Moscow: Nauka.

Dmitriev, Yu. D.(1998). Sosedi po planete. Zemnovodniye i presmikayushie [Neighbour on the planet. Amphibians and reptiles].Moscow: Olymp.

Fauconnier, G., Turner, M. (2006). Mental Spaces: Conceptual Integration Networks. Cognitive Linguistics: Basic Readings, 303-371.

Fauconnier, G. (1999). Mappings in Thought and Language. USA: Cambridge University Press.

Gura, A. V. (1997). Simvolika zhivotnikh v slavyanskoi narodnoi traditii [Symbolism of animal in Slavik folk traditions]. Moscow: Indrik.

Gura, A.V. (2002). Slavyanskaya myphologia [Slavic mythology]. (2 nd ed.). Moscow: Mezhdunarodniye otnosheniya.

Propp, V. la. (2000). Istoricheskie korni volshebnoy skazki [Historical roots of the fairy tale]. Moscow: Labirint.

Propp, V. Ia. (1997). Historical roots of the fairy tale. USA: Western Washington University.

Ralston, W.R.S. (2007). Russian Fairy Tales. A Choice Collection of Muscovite Folk-lore [Ebook]. From: http://www.gutenberg.org/files/ 22373/22373-h/22373-h.htm\#Page_158 (accessed 8 Sptember 2015).

Turner, M. (2014). The Origin of Ideas. New York: Oxford University Press. 